BIBLIOTIKA : Jurnal Kajian Perpustakaan dan Informasi

Volume 2 Nomor 2, 2018

Journal homepage : $\underline{\text { http://journal2.um.ac.id/index.php/bibliotika }}$

\title{
KECERDASAN EMOSIONAL PUSTAKAWAN DALAM MELAYANI PEMUSTAKA
}

Suryanto*, Gustina Erlianti

SMA Negeri 5 Malang, Universitas Negeri Padang

\begin{tabular}{l} 
A R T I C L E \\
I N F O \\
\hline
\end{tabular}

\section{Article bistory:}

Received: 6 Sep 2017

Accepted: 5 Dec 2017

Published: 15 Nov 2018

Kata Kunci:

Kecerdasan Emosional, Pustakawan, Pemustaka.

Keyword:

Emotional Intelligence, Librarian, User.

\begin{abstract}
A B S T R A C T
Kemampuan merasakan dan memahami secara lebih optimal terhadap sumber kepekaan emosi yang meliputi kemampuan memotivasi diri sendiri atau orang lain, pengendalian diri, mampu memahami perasaan orang lain dengan efektif, serta mampu mengelola emosi yang dapat digunakan untuk membimbing pikiran dalam mengambil keputusan yang terbaik. Cara yang paling sederhana untuk melatih kecerdasan emosional adalah dimulai dari menikmati pengalaman emosi yang dirasakan, ingatkan diri terkait emosi tersebut lalu praktekkan dengan baik emosi yang sedang dirasakan. Tulisan ini menyarankan kepada pustakawan untuk mengikuti pelatihan dan pengembangan diri serta dibuat kebijakan melayani pemustaka dengan senyum.
\end{abstract}

The ability to feel and understand more optimally the source of emotional sensitivity which includes the ability to motivate oneself or others, self-control, able to understand the feelings of others effectively, and be able to manage emotions that can be used to guide the mind in making the best decisions. The simplest way to train emotional intelligence is to start from enjoying the experience of the emotions that are felt, remind yourself of those emotions and then practice the emotions that are being felt well. This paper suggests librarians to take part in training and self-development and make policy to serve the user with a smile.

Perpustakaan sebagai pusat sumber informasi tidak akan lepas dari pengelolanya yaitu pustakawan. Pustakawan di sini tidak hanya dituntut untuk bisa menghimpun, mengolah, mengelola, mengemas, dan menyebarluaskan informasi tetapi ia juga harus mempunyai keterampilan sosial karena pekerjaannya cenderung lebih banyak berinteraksi dengan orangorang di sekitarnya (Almas, 2017). Salah satu aspek yang mempengaruhi pustakawan dalam berinteraksi dengan orang lain adalah emosi. Menurut James (Safaria, 2012: 1) emosi merupakan keadaan jiwa yang menampakkan diri dengan sesuatu perubahan yang jelas pada tubuh. Emosi

\footnotetext{
* Corresponding author.

E-mail addresses: suryanto.uya.dhuha@gmail.com (Suryanto)
}

ISSN : 2579-3802 (Online) - BIBLIOTIKA : Jurnal Kajian Perpustakaan dan Informasi is licensed under Creative Commons Attribution-ShareAlike 4.0 International License (http://creativecommons.org/licenses/BY/4.0/). 
juga dikategorikan menjadi dua kelompok yaitu emosi yang bernilai positif seperti senang, gembira, bersemangat maupun emosi yang bernilai negatif seperti marah, benci, cemas, gelisah, dan sebagainya.

Terkait dengan emosi dalam berinteraksi dengan pemustaka, tidak jarang kita mendengar image negatif mengenai pustakawan seperti seseorang yang galak, tidak ramah dan tidak pernah senyum. Padahal tidak selamanya demikian, terkadang pustakawan tersebut telah berupaya melayani pemustaka dengan sebaik dan seramah mungkin sesuai dengan Standar Operasional Prosedur (SOP) dan Standar Pelayanan Minimum (SPM), dikarenakan pemustaka mempunyai karakter yang berbeda-beda tetap saja bisa menimbulkan emosi negatif dari pustakawan yang pada kesimpulannya akan berpengaruh pada image negatif tentang pustakawan.

Hal ini diperjelas dalam cuplikan dialog antara pustakawan dan pemustaka yang menggambarkan sikap pemustaka yang tidak sopan, tidak memiliki tata krama, inginnya menyalahi aturan, bicaranya tinggi hati serta sikap dan bahasa tubuhnya yang menampakkan kesombongan sehingga pustakawan di sini dituntut untuk mempunyai kecerdasan emosional sehingga dapat memberikan layanan yang baik kepada pemustakanya (Fatmawati, 2010: 120).

Pentingnya kecerdasan emosional ini juga disampaikan oleh Ana (2014: 126) dalam penelitiannya yang berjudul "Hubungan Kecerdasan Emosional dan Profesionalitas Tenaga Perpustakaan di Kantor Perpustakaan dan Arsip Kabupaten Kulon Progo". Hasil dari penelitian ini adalah adanya hubungan yang signifikan antara kecerdasan emosional dengan profesionalistas kerja yang mana akan berdampak positif dalam melayani pemustaka.

Dengan demikian rumusan masalah dalam artikel berjudul "Kecerdasan Emosional Pustakawan Dalam Melayani Pemustaka" ini, apa yang dimaksud dengan emosi dan kaitannya dengan kecerdasan emosional, serta bagaimana cara mengelola emosi dan seberapa penting kecerdasan emosional bagi pustakawan dalam melayani pemustaka.

\section{LANDASAN TEORI \\ Definisi Emosi}

Emosi merupakan dorongan untuk bertindak, rencana seketika untuk menguasai masalah yang telah ditananamkan secara berangsur-angsur oleh evolusi. Menurut Goleman (2007:7), Akar dari kata emosi adalah movere, kata kerja yang bahasa latin yang berarti "menggerakkan, bergerak", ditambah awalan "e" untuk memberi arti "bergerak menjauh" yang menyiratkan bahwa kecenderungan untuk bertindak merupakan hal yang mutlak dalam emosi.

Adapun menurut James (Safaria,2012:11) emosi adalah keadaan jiwa yang menampakkan diri dengan sesuatu perubahan yang jelas pada tubuh. Jadi emosi merupakan cerminan dari keadaan jiwa yang akan tampak pada perubahan jasmani seseorang.

Menurut Goleman (2007:412), emosi dapat dikelompokkan menjadi beberapa jenis, diantaranya amarah, kesedihan, rasa takut, kenikmatan, cinta, terkejut, jengkel dan malu. Berdasarkan penjelasan Goleman, dapat disimpulkan bahwa emosi adalah reaksi terhadap suatu peristiwa atau kejadian yang bisa disikapi dengan positif maupun negatif oleh penerimanya.

\section{Kecerdasan Emosional dan Cara Pengelolaannya}

Kecerdasan emosional bukan didasarkan pada kepintaran seseorang tetapi pada sesuatu yang disebut dengan karakteristik pribadi yang mampu memandu pikiran untuk mengambil sebuah keputusan. Menurut Goleman (2007: 45), kecerdasan emosional atau Emotional Intelegence merupakan kemampuan untuk mengenali emosi diri sendiri, dan emosi orang lain yang menyatakan pada kemampuan memotivasi diri sendiri dan bertahan menghadapi frustasi; mengendalikan dorongan hati dan tidak melebih-lebihkan kesenangan; mengatur suasana hati dan menjaga agar beban stres tidak melumpuhkan kemampuan berfikir; serta berempati dan berdoa.

Adapun menurut Shapiro (2001:5), kecerdasan emosional merupakan himpunan suatu fungsi jiwa yang mengimplikasikan kemampuan memantau intensitas perasaan atau emosi, baik pada diri sendiri maupun pada orang lain. Individu yang mempunyai kecerdasan emosional yang tinggi memiliki keyakinan tentang dirinya sendiri, penuh antusias, pandai memilah semuanya dan 
menggunakan informasi sehingga dapat membimbing pikiran untuk mengambil keputusan yang terbaik.

Melalui kecerdasan emosional ini, seseorang akan belajar mengelola perasaannya sehingga dapat mengekspresikannya secara tepat dan efektif. Menurut Safaria (2012:121), ada tiga kiat umum untuk mengelola emosi antara lain, Menikmati pengalaman emosi yang dirasakan. Emosi ini sebagai sesuatu yang dapat datang dan pergi. Usahakan tidak menolak atau memelihara emosi, tetapi sikapi dengan bijaksana dan dengan sewajarnya. Kiat selanjutnya Ingatkan diri anda, apabila merasakan hal yang berbeda. Serta praktikkan dengan baik emosi yang anda rasakan. Cobalah untuk tidak menghakimi emosi anda. Ikuti dan terima emosi tersebut dengan tenang.

Berkaitan dengan pendapat di atas, Fatmawati (2010:121) juga menjelaskan dalam mengelola emosi harus mempunyai kecerdasan emosi yang bertumpu pada hubungan perasaan, watak, dan naluri moral. Hal ini bisa dijabarkan dalam bentuk luas, antara lain: Mampu mengendalikan diri, mempunyai semangat yang tinggi dalam bekerja, tekun/ rajin bekerja, sanggup memotivasi diri sendiri, mampu bertahan menghadapi rasa frustasi, mengatur semua perasaan dengan tidak berlebihan (terlalu sedih ataupun terlalu senang), dapat mengatur suasana hati dengan menjaga agar beban stress kerja tidak melumpuhkan kemampuan berpikir, mempunyai rasa empati terhadap orang lain, mampu menyelesaikan konflik, serta mampu memimpin diri sendiri beserta lingkungan sekitar kerjanya.

Berdasarkan beberapa pendapat di atas, dapat disimpulkan bahwa kecerdasan emosional adalah kemampuan merasakan dan memahami secara lebih efektif terhadap daya kepekaan emosi yang mencakup kemampuan memotivasi diri sendiri atau orang lain, pengendalian diri, mampu memahami perasaan orang lain dengan efektif, serta mampu mengelola emosi yang dapat digunakan untuk membimbing pikiran dalam mengambil keputusan yang terbaik.

\section{Komponen Dasar Kecerdasan Emosional}

Salovey (Goleman,2007:58) menyebutkan bahwa dalam kecerdasan emosional ada yang harus diperhatikan, yaitu: Harus Mengenali emosi diri dalam mengenali perasaan sewaktu perasaan itu terjadi atau bisa juga disebut dengan kemampuan untuk memantau perasaan dari waktu kewaktu. Kemudian kemampuan seseorang dalam mengendalikan emosi yang dirasakan secara tepat, menyadari hal-hal yang menyebabkannya, mencari cara mengatasinya, dan menampilkan reaksi yang sesuai. Kecerdasaan emosional juga diperhatikan dalam memotivasi diri sendiri dalam Kemampuan menyalurkan emosi dan menguasai diri untuk mencapai tujuan tertentu. Orang-orang yang memiliki keterampilan ini cenderung jauh lebih produktif dan efektif dalam hal apaun yang mereka kerjakan. Komponen dasar ini juga mengenali emosi orang lain untuk memahami orang lain, meliputi pemahaman terhadap perasaan, pikiran, dan keinginannya. Kemampuan ini lebih mengacu pada sikap empati. Setelah mengenali dan memahami diperlukan membina hubungan, maksud dari poin ini adalah kemampuan membina hubungan baik dan persahabatan dengan orang lain.

\section{Faktor-Faktor yang Mempengaruhi Kecerdasan Emosional}

Kecerdasan emosi tidak ditentukan sejak lahir tetapi dapat dilakukan melalui proses pembelajaran. Menurut Goleman (2007: 267-282), Ada beberapa faktor yang mempengaruhi kecerdasan emosi, yaitu: lingkungan keluarga, lingkungan non keluarga. Sedangkan menurut Joseph LeDoux dalam Goleman (2007:20-33), faktor-faktor yang mempengaruhi kecerdasan emosi antara lain: Fisik, Secara fisik bagian yang paling menentukan atau paling berpengaruh terhadap kecerdasan emosi seseorang adalah anatomi saraf emosinya. Bagian otak yang digunakan untuk berfikir yaitu konteks (kadang kadang disebut juga neo konteks). Sebagai bagian yang berada dibagian otak yang mengurusi emosi yaitu system limbik, tetapi sesungguhnya antara kedua bagian inilah yang menentukan kecerdasan emosi seseorang. 
Sedangkan factor yang mempengaruhi kecerdasan emosi adalah Psikis, Kecerdasan emosi selain dipengaruhi oleh kepribadian individu, juga dapat dipupuk dan diperkuat dalam diri individu.

Berdasarkan uraian tersebut dapat disimpulkan bahwa terdapat dua faktor yang dapat mempengaruhi kecerdasan emosi seseorang yaitu secara fisik dan psikis. Secara fisik terletak dibagian otak yaitu konteks dan sistem limbik, secara psikis diantaranya meliputi lingkungan keluarga dan lingkungan non keluarga.

\section{Manfaat Kecerdasan Emosional}

Kecerdasan emosional sangat berperan penting dalam keberhasilan seseorang baik ditempat kerja, tempat belajar, rumah, dan hubungan antar sesama maupun diri sendiri. Menurut Goleman (2007: 404), beberapa manfaat yang di peroleh apabila mempunyai kecerdasan emosional, antara lain: Mempunyai toleransi yang lebih tinggi baik terhadap diri sendiri maupun orang lain; Lebih mampu mengungkapkan amarah dengan tepat, tanpa harus berkelahi; Mampu meminimalisir emosi negatif dan mengubahnya menjadi emosi positif; Berkurangnya perilaku agresif atau merusak diri sendiri; Lebih bertanggung jawab dalam bekerja karena mampu memusatkan perhatian pada tugas yang sedang dikerjakan; Lebih tegas dan terampil dalam berkomunikasi dengan orang lain; Lebih demogratis dalam bergaul dan disenangi banyak orang

Adapun menurut Safaria (2012:10), kecerdasan emosional ini memegang peranan penting dalam menjalani kehidupan karena kecerdasan emosional ini mampu menghindarkan kita dari tekanan emosi yang berlebihan yang akan menyebabkan stres berkepanjangan yang berdampak pada kehidupan yang tidak tentram.

Berdasarkan pendapat di atas, dapat disimpulan bahwa dengan memiliki kecerdasan emosional seseorang akan merasa enjoy dalam menjalani hidup karena bisa mengatasi kemungkinan-kemungkinan terburuk yang suatu saat dapat terjadi dan akan menghindari diri dari sikap-sikap negatif yang dapat merugikan diri sendiri dan orang lain.

\section{PEMBAHASAN}

\section{Mengenal Emosi dan Kecerdasan Emosional}

Pada dasarnya emosi tidak bisa direncanakan untuk dihilangkan. namun emosi perlu dikelola dengan baik agar tidak menjadi masalah. Emosi di sini dapat di artikan sebagai reaksi terhadap suatu peristiwa atau kejadian yang bisa disikapi dengan positif maupun negatif oleh penerimanya. Biasanya dalam menyikapi emosi ini kita cenderung menghindari dan berusaha menghilangkan emosi negatif. Namun hal ini sangat sulit dilakukan. Oleh karena itu, kecerdasan emosional sangat penting karena akan membantu kita dalam meminimalisir emosi-emosi negatif yang mungkin saja terjadi tanpa kita duga.

\section{Kecerdasan Emosional Pustakawan}

Kecerdasan emosional merupakan kemampuan merasakan dan memahami secara lebih efektif terhadap daya kepekaan emosi yang mencakup kemampuan memotivasi diri sendiri atau orang lain, pengendalian diri, mampu memahami perasaan orang lain dengan efektif, dan mampu mengelola emosi yang dapat digunakan untuk membimbing pikiran dalam mengambil keputusan yang terbaik.

Orang yang memiliki kecerdasan emosi tinggi akan berupaya menciptakan keseimbangan diri dan lingkungannya, mengusahakan kebahagiaan dari dalam dirinya sendiri, dapat mengubah sesuatu yang buruk menjadi lebih baik, serta mampu bekerja sama dengan orang lain yang mempunyai latar belakang yang beragam.

Menyikapi pernyataan di atas, pustakawan untuk menjadi pribadi yang berprestasi memerlukan kemampuan dalam mengelola emosi baik emosi positif maupun emosi negatif. Emosi positif biasanya terjadi saat pustakawan merasa senang dengan pekerjaannya, merasa enjoy saat melayani pemustaka, dan memiliki rasa cinta terhadap perpustakaan. Sedangkan emosi negatif muncul saat sedang kesal dengan pemustaka, merasa iri hati/ dengki dengan rekan kerja, 
memendam rasa dendam dengan pimpinan, maupun hal-hal negatif lainnya. Mengingat kita tidak bisa mengontrol penyebab munculnya emosi negatif yang datang dari luar (eksternal), maka satusatunya yang masih dapat kita lakukan adalah dengan mengoptimalkan kecerdasan emosional yang kita miliki.

\section{Kemampuan Mengelola Emosi Pustakawan}

Dengan mengacu pada teori-teori mengenai kecerdasan emosional pada Bab II, dapat disimpulkan beberapa tindakan yang harus dipahami dan dipraktikkan pustakawan, kaitannya dengan kemampuan mengelola emosi, Tindakan tersebut antara lain:

1) Menyadari emosi, memperhatikan baik-baik beraneka ragam emosional diri sendiri yang sedang dirasakan (sedang sedih, sedang gembira, dan lain sebagainya). Dengan mengenali emosi diri sendiri kita dapat mengantisipasi perilaku-perilaku negatif yang mungkin muncul.

2) Mengakui emosi, caranya dengan memusatkan perhatian pada diri sendiri lalu berusaha mengakui dan mengatakan dengan jujur (misalnya: ya saya marah dengan si A, ya saya jengkel dengan si B, dan lain sebagainya). Dengan demikian beban emosi yang ada dalam diri kita dapat berkurang.

3) Menyelidiki emosi, caranya dengan menanyakan kepada diri pustakawan yang bersangkutan, misalnya: "Mengapa bisa terjadi seperti ini?" atau "Mengapa saya marah dan kesal?"

4) Mengungkapkan emosi yang tengah dialami kepada orang lain. Misalnya: sungguh hari ini saya merasa tegang, jangan-jangan sesuatu yang buruk akan terjadi pada diri saya atau ungkapan seperti ini "wah hari ini saya sangat senang karena gaji yang saya terima naik lima persen,"

5) Mengintegrasikan emosi, artinya pustakawan harus berusaha untuk selalu menggunakan akal sehat. Jadi lebih baik merencanakan untuk memulai lagi atau menyepakati untuk mengakhiri pembicaraan dengan lawan bicara.

Paparan di atas akan mengantarkan kita kepada satu simpulan penting. Pustakawan harus menyadari, menyiapkan "radar" saat emosi negatif semakin meninggi. semakin cepat disadari perubahan emosi itu, semakin cepat pula kita dapat mencari beragam solusi atas godaan untuk melampiaskan emosi negatif tersebut. Keterampilan mengelola emosi negatif terlebih di tempat kerja, sangat penting bagi pustakawan agar tujuan kerjanya dapat tercapai, sekaligus terlepas dari stres.

\section{Pentingnya Kecerdasan Emosional Pustakawan dalam Melayani Pemustaka}

Seperti yang telah dikemukakan oleh Goleman, manfaat yang dapat diperoleh jika mempunyai kecerdasan emosional, diantaranya adalah mempunyai toleransi yang lebih tinggi baik terhadap diri sendiri maupun orang lain, lebih mampu mengungkapkan amarah dengan tepat, tanpa harus berkelahi, mampu meminimalisir emosi negatif dan mengubahnya menjadi emosi positif, berkurangnya perilaku agresif atau merusak diri sendiri, lebih bertanggung jawab dalam bekerja karena mampu memusatkan perhatian pada tugas yang sedang dikerjakan, lebih tegas dan terampil dalam berkomunikasi dengan orang lain, serta lebih demogratis dalam bergaul dan disenangi banyak orang.

Dengan mengetahui beberapa manfaat di atas, dapat disimpulkan bahwa kecerdasan emosional memegang peranan penting dalam menunjang pekerjaan pustakawan sebagai penyedia dan pemberi layanan informasi kepada pemustaka karena dapat menuntun pustakawan dalam mengatasi berbagai situasi buruk yang mungkin terjadi pada saat bekerja.

Implementasi Kecerdasan Emosional dalam Melayani Pemustaka 
Penerapan kecerdasan emosional ini pada perpustakaan bisa dilihat dari cara pustakawan dalam melayani pemustakanya. Misalnya dengan mengadopsi teori CARE yang dapat dirinci sebagai berikut:

1. $\mathrm{C}=$ Concern, yaitu kepedulian pustakawan terhadap pemustaka

Kepedulian terhadap pemustaka di sini dapat dilihat dari sikap pustakawan yang peka dan siap membantu ketika melihat pemustaka yang kebingungan dalam mencari informasi yang sesuai dengan kebutuhannya.

2. $\mathrm{A}=$ Attention, yaitu perhatian pustakawan terhadap pemustaka

Dalam melayani pemustaka, pustakawan hendaknya bisa mendekatkan diri dengan pemustakanya sehingga terjadi kedekatan antara kedua belah pihak. Salah satu hal yang dapat dilakukan oleh pustakawan adalah dengan memberikan perhatian kepada pemustaka, sehingga pemustaka merasa puas dan senang atas perilaku yang diterimanya.

3. $\mathrm{R}=$ Relation, yaitu hubungan yang diciptakan antara pustakawan dengan pemustaka

Pustakawan dengan pemustaka harus memiliki hubungan yang baik agar informasi yang disampaikan baik dari pemustaka ataupun pustakawan dapat dicerna dengan baik. Dengan menciptakan hubungan yang baik ini, otomatis akan menarik pemustaka untuk selalu berkunjung ke perpustakaan dan akan terciptanya image postif dari pustakawan itu sendiri.

4. $\mathrm{E}=$ Emotion, yaitu emosi yang terbina antara pustakawan dengan pemustaka

Dalam berinteraksi dengan pemustaka, pustakawan harus mampu mengelola emosi agar terciptanya emosi positif sehingga terjalin hubungan baik antara pustakawan dan pemustaka.

Dengan menerapkan sistem ini, diharapkan dapat mengubah image negatif yang selama ini melekat pada diri pustakawan sehingga dapat menciptakan lingkungan yang harmonis antara pustakawan dengan pemustaka.

\section{SIMPULAN}

Emosi merupakan reaksi terhadap suatu peristiwa atau kejadian yang bisa disikapi dengan positif maupun negatif oleh penerimanya. Dalam menyikapi kejadian tersebut dibutuhkanlah kecerdasan emosional yang dapat diartikan sebagai kemampuan seseorang dalam mengelola emosi dalam diri sehingga dapat meminimalisir kemungkinan munculnya emosi-emosi negatif dalam menjalani hidup.

Cara yang paling sederhana untuk mengasah kecerdasan emosional adalah dimulai dari menikmati pengalaman emosi yang dirasakan, ingatkan diri terkait emosi tersebut lalu praktekkan dengan baik emosi yang sedang dirasakan.

Pustakawan sebagai salah satu profesi yang memberikan layanan informasi otomatis tidak akan lepas dari hubungan interaksi dengan pemustakanya. Oleh karena itu dibutuhkan kecerdasan emosional agar mampu mengelola emosi dengan baik dalam melayani pemustaka yang beraneka ragam.

Mengingat pentingnya kecerdasan emosional bagi pustakawan dalam melayani pemustaka, disarankan kepada pustakawan untuk mengikuti pelatihan dan pengembangan diri agar mampu mengelola emosinya dalam melayani pemustaka sehingga dapat memberikan pelayanan yang optimal kepada pemustaka.

Selain itu perlu adanya terobosan baru tentang kebijakan yang mewajibkan pustakawan untuk senyum kepada pemustaka, walaupun awalnya terasa berat, namun apabila dibiasakan akan terasa mudah sehingga dapat menciptakan suasana nyaman, dan harmonis yang dapat meningkatkan emosi positif setiap orang yang berada di lingkungan perpustakaan.

Dalam hal ini perpustakaan juga bisa mengadopsi teori CARE yaitu: Concern (kepedulian pustakawan terhadap pemustaka); Attention (perhatian pustakawan terhadap pemustaka); Relation (hubungan yang diciptakan antara pustakawan dengan pemustaka) dan Emotion (emosi yang terbina antara pustakawan dengan pemustaka).

Dengan menerapkan beberapa saran tersebut, diharapkan dapat meningkatkan kinerja pustakawan dalam memberikan layanan kepada pemustaka serta dapat mengubah image negatif pustakawan dimata masyarakat sehingga dapat menarik masyarakat untuk datang ke perpustakaan. 


\section{DAFTAR PUSTAKA}

Almas, H. (2017). MANAJEMEN SISTEM INFORMASI DI PERPUSTAKAAN SMK

NEGERI 3 MALANG. BIBLIOTIKA : Jurnal Kajian Perpustakaan Dan Informasi, 1(1), 91 100. https://doi.org/10.17977/um008v1i12017p091

Ana, V. S. (2014). "Hubungan Kecerdasan Emosional dan Profesionalitas Tenaga Perpustakaan di Kantor Perpustakaan dan Arsip Kabupaten Kulon Progo", Skripsi, Yogyakarta: S1 Ilmu Perpustakaann Universitas Islam Negeri Sunan Kalijaga.

Fatmawati, E. (2010). The Art of Library: Ikatan Esai Bergizi tentang Seni Mengelola Perpustakaan. Semarang: Badan Penerbit Universitas Diponegoro Semarang.

Goleman, D. (2007). Emotional Intellegence. Jakarta: Gramedia.

Safaria, T dan Nofrans E. S. (2012). Manajemen Emosi: Sebuah Panduan Cerdas Bagaimana Mengelola Emosi Positif dalam Hidup Anda. Jakarta: Bumi Aksara.

Shapiro, E.L. (2001). Mengajarkan Emotional Intelegence Pada Anak. Jakarta: Gramedia Pustaka Utama. 